\title{
Proposal of a practical diet for juvenile astacid crayfish studies from the onset of exogenous feeding under controlled conditions
}

\author{
J.M. Carral(1), Á. González ${ }^{(1)}$, J.D. Celada(1) M. Sáez-Royuela(1), V. García ${ }^{(1)}$, \\ R. González ${ }^{(1)}$
}

Received January 7, 2011

Revised March 4, 2011

Accepted April 19, 2011

Key-words: astacid, juvenile, feeding, practical diet

\section{ABSTRACT}

Considering the knowledge on freshwater crayfish feeding requirements and other cultured crustaceans, a practical extruded diet was formulated with the aim to be used for juvenile astacid studies from the onset of exogenous feeding. According to a bifactorial design, the practical diet was compared with the diet which has allowed repeated good survival and growth results (control: feedstuff for trout combined with Artemia cysts) in groups and individually isolated crayfish in an 80-day experiment. Diets tested did not affect final survival rates and growth neither in grouped nor in isolated crayfish, being the highest survival rate (average: 93\%) and growth values (average: $13.2 \mathrm{~mm}$ carapace length: $C L, 578.1 \mathrm{mg}$ weight: $W, 3.52 \% \cdot d^{-1}$ specific growth rate: SGR, $1896.6 \%$ weight gain: $\left.W G\right)$ reached with the practical diet. Survival rates did not show significant differences neither among crayfish maintained in groups (86\% for the practical diet and $81.7 \%$ for the control diet) nor among isolated crayfish (100\% survival). Isolated crayfish had significantly higher growth (14.3 $\mathrm{mm} \mathrm{CL}$, $760 \mathrm{mg} W$ ) than the grouped crayfish (11.5 mm CL, $354 \mathrm{mg} \mathrm{W}$ ). Results show the feasibility of the proposed practical diet as basis for further studies on astacid crayfish.

\section{RÉSUMÉ}

Proposition d'une nourriture pratique pour les études de juvéniles d'écrevisses dès la prise de nourriture exogène sous conditions contrôlées

Mots-clés :
astacidé,
juvénile,
alimentation,
nourriture
pratique

Mots-clés : astacidé, juvénile, nourriture pratique

Étant donné les connaissances sur les besoins alimentaires des écrevisses d'eau douce et d'autres crustacés élevés, une nourriture extrudée pratique a été formulée dans le but d'être utilisée pour les études sur les juvéniles d'astacidés dès la prise de nourriture exogène. Selon un dispositif bifactoriel, la nourriture a été comparée à une alimentation qui a permis de bonnes survie et croissance (contrôle : nourriture pour truite avec des cystes d'Artemia) dans des expérimentations de 80 jours sur individus isolés ou en groupe. Les alimentations testées n'affectent pas les taux de survie finaux et la croissance que ce soit sur des écrevisses en groupe ou isolées, les taux de survie (moyenne : $93 \%$ ) et valeurs de croissance (moyenne : 13,2 mm de longueur de carapace : $C L ; 578,1 \mathrm{mg}$ en poids : W; 3,52 \%.jour ${ }^{-1}$, croissance spécifique : SGR; $1896,6 \%$, en gain de poids : WG) sont les meilleurs avec l'alimentation pratique. Les taux de survie ne présentent pas de

(1) Dpto. de Producción Animal, Facultad de Veterinaria, Universidad de León, Campus de Vegazana s/n, 24071 León, Spain, jmcarl@unileon.es 
différences significatives que les écrevisses soient en groupes (86 \% avec la nourriture pratique et $81,7 \%$ avec le témoin) ou isolées (100\% de survie). Les écrevisses isolées ont une croissance significativement meilleure (14,3 mm CL, $760 \mathrm{mg} W$ ) que celles en groupe (11,5 mm CL, $354 \mathrm{mg} W$ ). Ces résultats montrent la faisabilité de cette nourriture pour des études ultérieures sur les écrevisses.

\section{INTRODUCTION}

One the main constraints to interpret and compare research results of different crustacean species is the lack of standardization in experimental methodology (D'Abramo and Castell, 1997). The recommendations proposed by New (1976) highlights the development of a standard reference to facilitate the comparison of data not only in nutrition research, but also in studies on crustacean culture technology such as general physiology, behaviour, disease and so on.

A standard reference diet for crustaceans (Castell, 1989), formulated for lobster (Homarus spp.), was evaluated in a wide range of crustaceans including some species of astacid crayfish (Celada et al., 1989; Ackefors et al., 1992). In addition to the poor results obtained on freshwater crayfish, the limited supply and high price of this diet discouraged its further use on crayfish research.

A wide variety of natural foods (mainly fresh or frozen animals and vegetables) and feedstuffs formulated for other aquatic species either alone or supplemented with natural foods (see review by González R. et al., 2009a) have been tested to improve survival and growth rates of astacid juveniles from the onset of exogenous feeding. However, acceptable results have been only obtained by supplying live feed such as Daphnia or Artemia nauplii (Sáez-Royuela et al., 2007; González À. et al., 2008, 2011; González R. et al., 2009a). Recently, González R. et al. (2009b) proved that decapsulated Artemia cysts can be better supplement than live nauplii, since cysts improve the performance of juvenile crayfish, allowing a reduction of labour and costs. These improvements on feeding schedules during the first months of independent life open the possibility of approaching a new step, the formulation of a specific practical diet for astacid crayfish.

\section{MATERIAL AND METHODS}

\section{>CRAYFISH, FACILITIES AND EXPERIMENTAL PROCEDURE}

An 80-day experiment was carried out in indoor facilities starting with stage 2 juvenile Pacifastacus leniusculus Dana (mean: $5.64 \pm 0.05 \mathrm{~mm}$ carapace length and $28.94 \pm$ $0.7 \mathrm{mg}$ weight) hatched in the laboratory. Juvenile crayfish were maintained in groups at a density of $100 \cdot \mathrm{m}^{-2}$ and, in order to set adequate experimental conditions, isolation of crayfish was also considered to avoid possible influence of intraspecific behavioural interactions such as cannibalism. Following a bifactorial design, two diets were tested on groups (three tanks for each treatment, $N=25$ per tank) and individually isolated animals (five replicates for each treatment). Crayfish in groups were held in opaque rectangular fibreglass tanks $\left(0.25 \cdot \mathrm{m}^{-2}\right)$ at a density of $100 \cdot \mathrm{m}^{-2}$, whereas isolated animals were maintained in smaller tanks $\left(0.125 \cdot \mathrm{m}^{-2}\right)$. In both cases, PVC pipes $(4 \mathrm{~cm}$ long $\times 20 \mathrm{~mm}$ diameter) were used as shelter. Aerated artesian well water was supplied in open system, and each tank had its own water inlet and outlet. Quality parameters of the incoming water were $\mathrm{pH} 7.8$, hardness $18^{\circ} \mathrm{f}$ (French grades, calcium $72 \mathrm{mg} \cdot \mathrm{L}^{-1}$ ), total dissolved solids $205.2 \mathrm{mg} \cdot \mathrm{L}^{-1}$ and total suspended solids $13.9 \mathrm{mg} \cdot \mathrm{L}^{-1}$. Throughout the trial, oxygen content was measured in the tanks, ranging from 
$5.9 \mathrm{mg} \cdot \mathrm{L}^{-1}$ to $7.9 \mathrm{mg} \cdot \mathrm{L}^{-1}$ (average values around $7 \mathrm{mg} \cdot \mathrm{L}^{-1}$ ). Ammonia and nitrite were measured from water samples taken inside the tanks (values were always ammonia $<0.02 \mathrm{mg} \cdot \mathrm{L}^{-1}$ and nitrite $\left.<0.05 \mathrm{mg} \cdot \mathrm{L}^{-1}\right)$. Water temperature was maintained at $22 \pm 1{ }^{\circ} \mathrm{C}$. Photoperiod was natural (ca. $14 \mathrm{~h}$ light and $10 \mathrm{~h}$ dark). Tanks were cleaned twice a week.

\section{> DIETS AND FEEDING}

Based on the available knowledge on freshwater crayfish feeding and on recent advances, ingredients for a practical diet were chosen. Vitamins levels were included following the recommendations made by Conklin (1997) for different crustacean species and Akiyama et al. (1992) for shrimps. In the case of minerals, the information provided by Davis and Arnold (2000) was applied. The efficacy of the practical diet from the onset of exogenous feeding was compared with the diet which has allowed good results in previous studies: a feedstuff for trout supplemented with Artemia cysts (González R. et al., 2009b, 2011). Crayfish were manually fed to excess (ca. $2.5 \%$ body weight per day) once a day.

In crayfish held both in groups and individually isolated, two diets were tested:

- Control: A dry diet for salmonids (T-NUTRA-0, Skretting, Trouw España SA. Cojobar, Burgos, Spain, composition data provided by the manufacturer: crude protein $54 \%$, crude lipid $18 \%$, crude cellulose $0.08 \%$, ashes $12 \%$, total phosphorus $1.8 \%$, Vitamine A $10000 \mathrm{UI} \cdot \mathrm{kg}^{-1}, \mathrm{D}_{3} 1500 \mathrm{UI} \cdot \mathrm{kg}^{-1}, \mathrm{E} 150 \mathrm{mg} \cdot \mathrm{kg}^{-1}$, gross energy $19.3 \mathrm{~kJ} \cdot \mathrm{kg}^{-1}$, pellet diameter 0.9-1.5 mm) supplemented with decapsulated Artemia cysts (cysts of INVE Aquaculture Nutrition, High HUFA $430 \mu \mathrm{m}$, Hoogveld 91, Dendermonde, Belgium). Cysts were decapsulated according to the method described by Van Stappen (1996). The initial amount of Artemia supplement was 500 cysts per crayfish per day (later increasing by $15 \%$ considering biomass values calculated every 20 days). Supplement assessment was performed from the number of cysts $\cdot \mathrm{g}^{-1}$ provided by the manufacturer.

- Practical diet: Ingredients were mixed and extruded using the stand-alone extruder Brabender E19/25 D (Diusburg, Germany) at a temperature range between $75{ }^{\circ} \mathrm{C}$ and $90{ }^{\circ} \mathrm{C}$ and then dried during $24 \mathrm{~h}$ at $30^{\circ} \mathrm{C}$. Later, pellets $(1 \mathrm{~mm}$ diameter) received a coating of cod liver oil. Pellet size was adjusted to $2 \mathrm{~mm}$. Diet composition is summarized in Table I.

\section{> DATA COLLECTION AND ANALYSIS}

Every twenty days, crayfish were counted and survival rates calculated. After removing excess water with tissue paper, all survivors were weighed and measured individually. Subsequently, animals were gently returned to their respective tanks. Carapace length $(C L)$ was measured with a digimatic calliper (to the nearest $0.01 \mathrm{~mm}$ ) and wet individual weight $(W)$ was determined by means of a precision balance (to the nearest $0.1 \mathrm{mg}$ ). Specific growth rate (SGR) and weight gain (WG) were expressed as $\left(\ln W_{t}-\ln W_{i}\right) \times 100 / T$ and $\left(W_{t}-W_{i}\right) 100 / W_{i}$, respectively, where $W_{t}$ is the mean final weight $(\mathrm{mg}), W_{i}$ is the mean initial weight, and $T$ is the period (days). At the end of the experiment, survival percentages were calculated and all surviving crayfish were weighed and measured individually.

Results were examined by analysis of variance (ANOVA) using the computer program SPSS 16 (SPSS Inc. Chicago, III., USA). Duncan test was applied to compare means at the $P<0.05$ level of significance. Percentages were arcsine-transformed prior to statistical analysis.

\section{RESULTS AND DISCUSSION}

Final survival and growth values ( 80 days) are presented in Table II. Diets tested did not affect final survival rates and growth values neither in grouped animals nor in individually isolated 


\section{Table I}

Composition of the practical extruded diet.

Tableau I

Composition de l'aliment extrudé.

\begin{tabular}{|c|c|}
\hline \multicolumn{2}{|l|}{ Ingredients (\%) } \\
\hline Fish meal $^{1}$ & 61.48 \\
\hline Corn meal $^{2}$ & 13.0 \\
\hline Cod-liver oil ${ }^{3}$ & 3 \\
\hline Soy lecithin ${ }^{4}$ & 0.1 \\
\hline Cholesterol $^{5}$ & 0.5 \\
\hline Ascorbyl monophosphate ${ }^{6}$ & 0.04 \\
\hline Choline chloride $^{6}$ & 0.5 \\
\hline Dicalcium phosphate $^{6}$ & 1.0 \\
\hline Dried decapsulated Artemia cysts $^{7}$ & 15.0 \\
\hline Carboxymethylcellulose $^{8}$ & 3.0 \\
\hline Astaxanthin ${ }^{9}$ & 0.1 \\
\hline Vitamin premix ${ }^{10}$ & 0.28 \\
\hline Mineral premix ${ }^{11}$ & 2.0 \\
\hline \multicolumn{2}{|l|}{ * Proximate composition (\%) } \\
\hline Moisture & 8.3 \\
\hline Crude protein & 50.22 \\
\hline Lipids & 12.14 \\
\hline Carbohydrates & 12.33 \\
\hline Ashes & 13.23 \\
\hline Fiber & 3.78 \\
\hline Gross energy $\left(\mathbf{k J} \cdot \mathrm{g}^{-1}\right)$ & 19.33 \\
\hline
\end{tabular}

\footnotetext{
* It was calculated from the known composition of each ingredient

${ }^{1}$ BIOMAR Iberia / PROAQUA Nutrición, Dueñas (Palencia), Spain.

${ }^{2}$ ADPAN, Siero-Asturias, Spain.

${ }^{3}$ ACOFARMA, Terrassa (Barcelona), Spain.

${ }^{4}$ BIOVER NV/SA Brujas, Belgium.

5 Sigma-Aldrich Chemie GMBH, Steinheim, Germany.

${ }^{6}$ NUTRAL SA, Madrid, Spain.

7 Artemia cysts INVE Aquaculture Nutrition, High HUFA $430 \mu \mathrm{m}$, Dendermonde, Belgium.

8 HELM IBERICA SA, Madrid, Spain.

9 BIOMAR Iberia / PROAQUA Nutrición, Dueñas (Palencia), Spain.

10 (mg.100 g ${ }^{-1}$ premix): Thiamine 2142.9; Riboflavin 1892.9; Niacin 7142.9 ; Pyridoxine 1785.7; Pantothenic acid 3785.7; Biotin 35.7; Folic acid 571.4; Cyanocobalamin 7.1; Myoinositol 14285.7; Retinol 53.7; $\alpha$-tocopherol 2382.1; Cholecalciferol 392.86; Naphthoquinone 312.43; Ethoxyquin 3571.43.

11 (mg.100 g ${ }^{-1}$ premix): $\mathrm{CoCl}_{2} 4 ; \mathrm{CuSO}_{4}-5 \mathrm{H}_{2} \mathrm{O}$ 250; $\mathrm{FeSO}_{4} 4000 ; \mathrm{MgSO}_{4}-7 \mathrm{H}_{2} \mathrm{O} 28398 ; \mathrm{MnSO}_{4}-\mathrm{H}_{2} \mathrm{O}$ 650; KI 67; $\mathrm{Na}_{2} \mathrm{SeO}_{3} 10 ; \mathrm{ZnSO}_{4}-7 \mathrm{H}_{2} \mathrm{O} 13193$.
}

animals. Figures 1 and 2 show the carapace length and weight, respectively, throughout the 80 days when crayfish were fed the control diet or the practical diet. In the different checks, no differences in carapace length and weight were found between the tested diets in both isolated and grouped crayfish. Regardless of whether the animals were kept isolated or in groups, no differences were detected between the practical diet (average: 93.0\% survival, $13.19 \mathrm{~mm} C L, 578.12 \mathrm{mg} \mathrm{W}, 3.52 \% \cdot \mathrm{d}^{-1} \mathrm{SGR}$ and $1896.6 \% \mathrm{WG}$ ) and the control diet (average: 90.8\% survival, $12.72 \mathrm{~mm} \mathrm{CL}, 536 \mathrm{mg} W, 3.44 \% \cdot \mathrm{d}^{-1}$ SGR and $\left.1748.1 \% W G\right)$.

For both diets tested, individually isolated crayfish had final higher survival rate and growth values than the grouped crayfish (Table II). Figures 3 and 4 show the changes in carapace length and weight, respectively, throughout the 80 days when crayfish were maintained in groups or isolated. Since the first check (20 days), isolated crayfish grew faster than the grouped crayfish. At the end of the experiment (80 days) and regardless of the diet supplied,

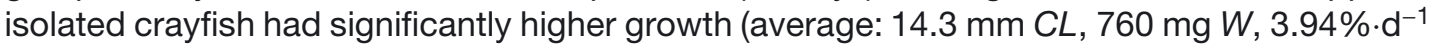




\section{Table II}

Final survival and growth values (80 days) of juvenile crayfish held in groups or individually isolated, fed the control diet or the proposed practical diet.

\section{Tableau II}

Survie finale et croissance (à 80 jours) des juvéniles d'écrevisses tenues en groupe ou isolées nourries avec la nourriture témoin ou proposée.

\begin{tabular}{|l|c|c|c|c|}
\cline { 2 - 5 } \multicolumn{1}{c|}{} & \multicolumn{2}{c|}{ Control diet } & \multicolumn{2}{c|}{ Practical diet } \\
\cline { 2 - 5 } \multicolumn{1}{c|}{} & Groups & Isolated & Groups & Isolated \\
\hline Survival (\%) & $81.7 \pm 5.8^{\mathrm{a}}$ & $100^{\mathrm{b}}$ & $86.0 \pm 3.40^{\mathrm{a}}$ & $100^{\mathrm{b}}$ \\
\hline $\boldsymbol{C L}(\mathbf{m m})$ & $11.31 \pm 0.21^{\mathrm{a}}$ & $14.14 \pm 0.26^{\mathrm{b}}$ & $11.82 \pm 0.28^{\mathrm{a}}$ & $14.57 \pm 0.98^{\mathrm{b}}$ \\
\hline $\boldsymbol{W}(\mathbf{m g})$ & $330.65 \pm 20.75^{\mathrm{a}}$ & $741.40 \pm 123.32^{\mathrm{b}}$ & $377.65 \pm 27.38^{\mathrm{a}}$ & $778.60 \pm 171.09^{\mathrm{b}}$ \\
\hline SGR (\%) & $2.97 \pm 0.07^{\mathrm{a}}$ & $3.91 \pm 0.32^{\mathrm{b}}$ & $3.07 \pm 0.10^{\mathrm{a}}$ & $3.99 \pm 0.66^{\mathrm{b}}$ \\
\hline WG (\%) & $1033.8 \pm 61.45^{\mathrm{a}}$ & $2462.5 \pm 610.3^{\mathrm{b}}$ & $1204.9 \pm 94.6^{\mathrm{a}}$ & $2590.4 \pm 591.8^{\mathrm{b}}$ \\
\hline
\end{tabular}

Values are mean \pm mean standard error.

Values in the same row having different superscript are significantly different $(P<0.05)$.

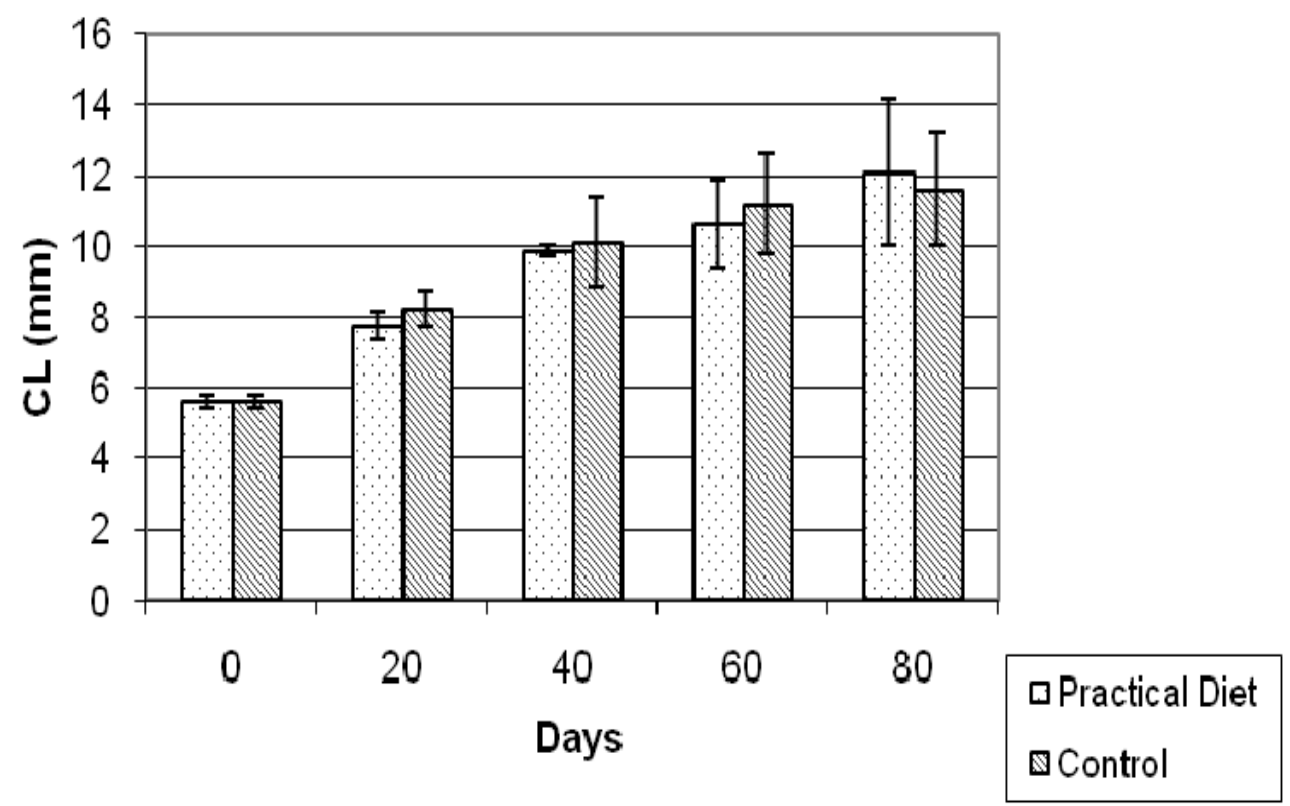

\section{Figure 1}

Mean carapace length $C L( \pm S D)$ of juvenile crayfish fed the control diet or the practical diet in the checks throughout the experimental period.

\section{Figure 1}

Longueur moyenne de la carapace CL (avec déviation standard) des juvéniles d'écrevisses nourris avec la nourriture témoin ou proposée pendant la période de l'expérimentation.

SGR and 2526.4\% WG) than the grouped crayfish (average: $11.5 \mathrm{~mm} \mathrm{CL}, 354 \mathrm{mg} \mathrm{W}$, $3.02 \% \cdot d^{-1}$ SGR and $1119.3 \%$ WG). In previous studies (Celada et al., 1989, 1993; SáezRoyuela et al., 1995), crayfish in groups had higher growth than those isolated. This fact was explained by the poor quality of the diets provided, which was the only food available for isolated animals, whereas the maintained in groups had a food supplement provided by cannibalism. In the present experiment, the use of an improved diet allowed that isolated crayfish, free from the stress generated by foraging competition and aggressive behavior with mates, could better express their growth potential.

The proposed practical diet enabled similar performance after 80 days in terms of survival and growth than the control diet previously used by González R. et al. (2009b, 2011). Considering that the Artemia cysts availability guarantee the success of astacid crayfish breeding from 


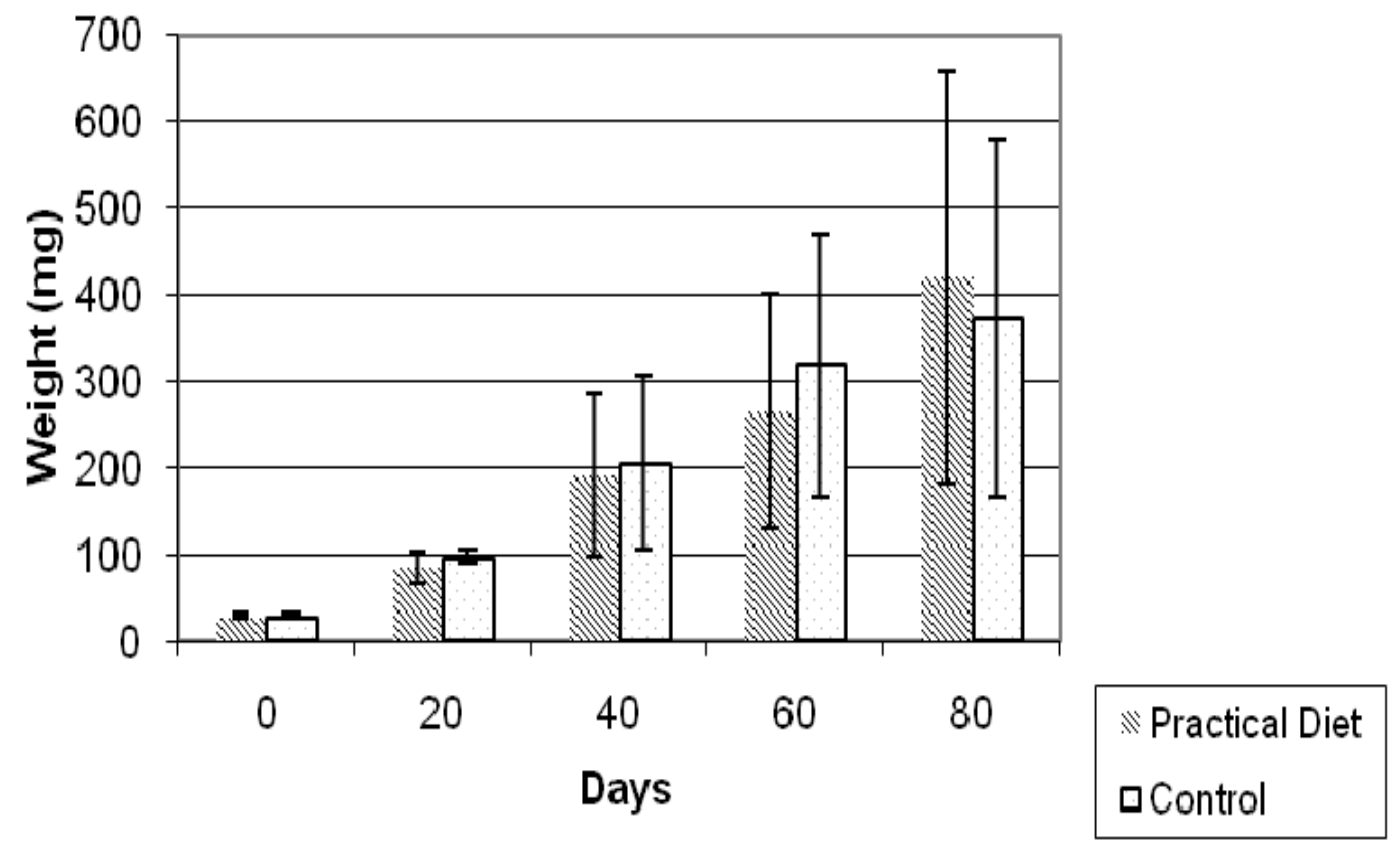

Figure 2

Mean weight $( \pm S D$ ) of juvenile crayfish fed the control diet or the practical diet in the checks throughout the experimental period.

\section{Figure 2}

Poids moyen (avec déviation standard) des juvéniles d'écrevisses nourries avec la nourriture témoin ou proposée pendant la période de l'expérimentation.

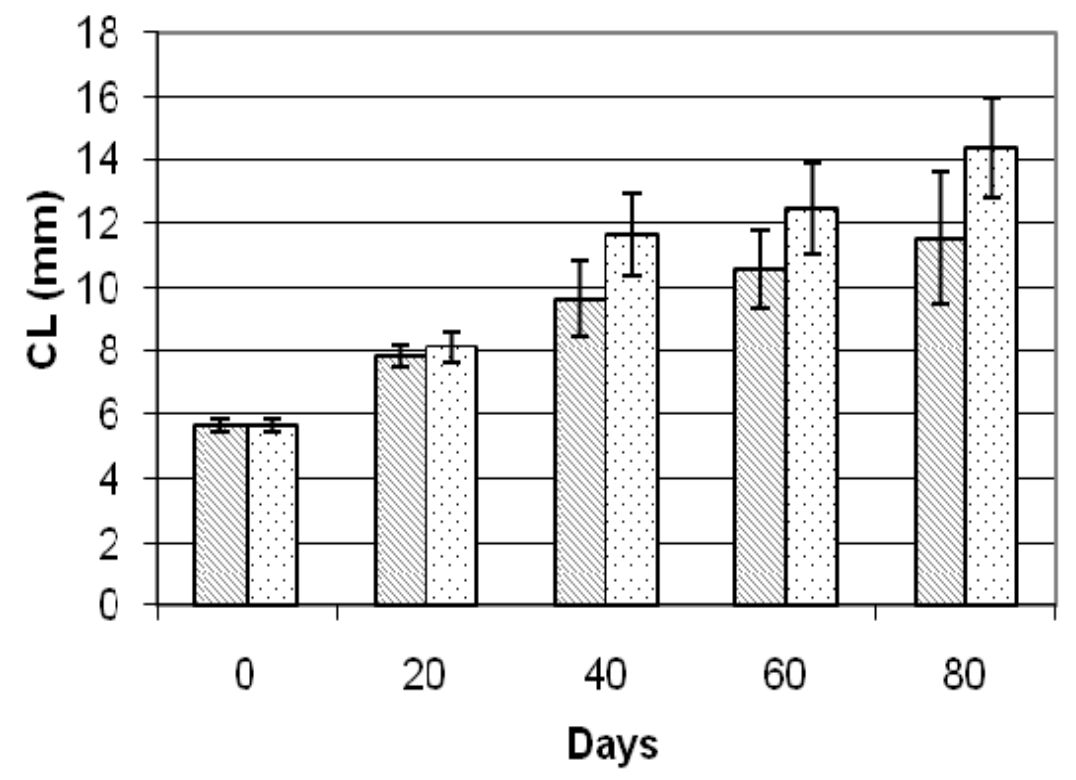

GGroups DIsolated

Figure 3

Mean carapace length $( \pm S D$ ) of juvenile crayfish held in groups or isolated in the checks throughout the experimental period. 


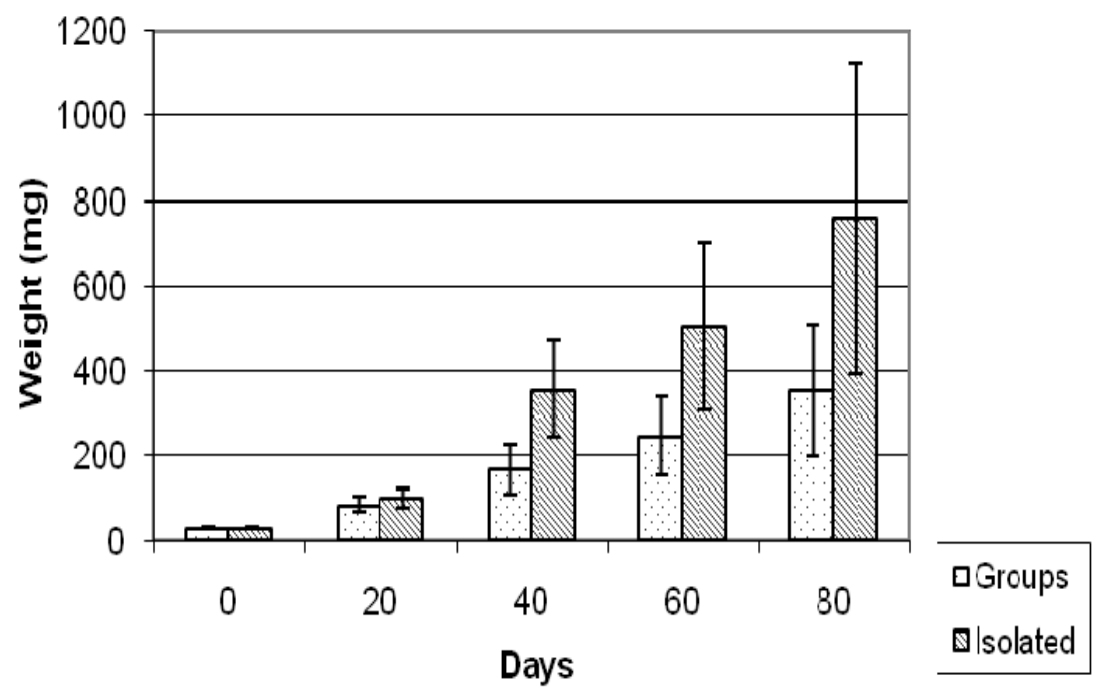

\section{Figure 4}

Mean weight $( \pm S D$ ) of juvenile crayfish held in groups or isolated in the checks throughout the experimental period.

\section{Figure 4}

Poids moyen (avec déviation standard) des juvéniles d'écrevisses tenues en groupes ou isolées pendant la période de l'expérimentation.

the onset of exogenous feeding, a small amount of cysts was included in the practical diet. Despite the significant reduction of cysts compared to those supplied in the control diet, both diets did not show differences in the performance of juvenile crayfish, allowing an important saving of brine shrimp cysts. In addition, this practical diet avoids the need of combining several foods and can be handled as a commercial dry diet. In order to make feasible its use and following the suggestions made by D'Abramo and Castell (1997), the practical diet was formulated with a small number of ingredients, all easily available, minimizing the eventual inability to get regularly a particular ingredient. From the good results obtained, the proposed practical diet show its feasibility to be used as basis for further studies on freshwater crayfish under controlled conditions, preventing distortion or masking of experimental results caused by a deficient feeding.

\section{ACKNOWLEDGEMENTS}

Funding of this study was the Plan Nacional de $\mathrm{I}+\mathrm{D}+\mathrm{i}$, Ministerio de Educación y Ciencia, Spain, Research Project AGL2005-01127. We thank the financing of a grant for Programa Nacional de Formación de Profesorado Universitario, Ministerio de Educación y Ciencia, Spain, reference AP2005-4860. We should also like to thank the Quiñón S.A. crayfish farm and Nutral S.A. for their collaboration.

\section{REFERENCES}

Ackefors H., Castell J.D., Boston L.D., Räty P. and Svensson M., 1992. Standard experimental diets for crustacean nutrition research. II. Growth and survival of juvenile crayfish Astacus astacus (Linné) fed diets containing various amounts of protein carbohydrate and lipid. Aquaculture, 104, 341-356.

Akiyama D.M., Dominy W.G. and Lawrence A.L., 1992. Penaeid shrimp nutrition. In: Fasy E.W. and Lester L.J. (eds.), Marine Shrimp Culture: Principles and Practices, Elsevier Science Publishers, B.V. Amsterdam, 535-568. 
Castell D.L., 1989. Reference diet for crustaceans: principles of experimentation. In: Advances in Tropical Aquaculture, Actes de Colloque 9, Aquacop, IFREMER, 339-354.

Celada J.D., Carral J.M., Gaudioso V.R., Temiño C. and Fernández R., 1989. Response of juvenile freshwater crayfish (Pacifastacus lenisculus Dana) to several fresh and artificially compounded diets. Aquaculture, 76, 67-78.

Celada J.D., Carral J.M., Gaudioso V.R., González J., Lopez-Baissón C. and Fernandez R., 1993. Survival and growth of juvenile freshwater crayfish Pacifastacus leniusculus Dana fed two raw diets and two commercial formulates feeds. J. World Aquacult. Soc., 24, 108-111.

Conklin D.E., 1997. Vitamins. In: D’Abramo L.R., Conklin D.L. and Akiyama D.M. (eds.), Crustacean Nutrition, Advances in World Aquaculture, Vol. 6, World Aquaculture Society, Baton Rouge, Louisiana, 1233-149.

D’Abramo L.R. and Castell J.D., 1997. Research methodology. In: D’Abramo L.R., Conklin D.L. and Akiyama D.M. (eds.), Crustacean Nutrition, Advances in World Aquaculture, Vol. 6, World Aquaculture Society, Baton Rouge, Louisiana, 3-25.

Davis D.A. and Arnold C.R., 2000. Replacement of fish meal in practical diets for the Pacific white shrimp, Litopenaeus vannamei. Aquaculture, 185, 291-298.

González Á., Celada J.D., González R., García V., Carral J.M. and Sáez-Royuela M., 2008. Artemia nauplii and two commercial replacements as dietary supplement for juvenile signal crayfish, Pacifastacus leniusculus (Astacidae), from the onset of exogenous feeding under controlled conditions. Aquaculture, 281, 83-86.

González Á., Celada J.D., Sáez-Royuela M., González R., Carral J.M. and García V., 2011. Response of juvenile astacid crayfish (Pacifastacus leniusculus) to three commercial dry diets with different protein levels during the first six months of intensive rearing. Aquaculture Research, doi: 10.1111/j1365-2109.2011.02808.x.

González R., Celada J.D., González Á., García V., Carral J.M. and Sáez-Royuela M., 2009a. Stocking density for the intensive rearing of juvenile crayfish, Pacifastacus leniusculus (Astacidae), using Artemia nauplii to supplement a dry diet from the onset of exogenous feeding. Aquaculture International, 18, 371-378.

González R., Celada J.D., Carral J.M., González Á., Sáez-Royuela M. and García V., 2009b. Decapsulated Artemia cysts as dietary supplement for juvenile crayfish (Pacifastacus leniusculus, Astacidae) at different food supply frequencies from the onset of exogenous feeding under controlled conditions. Aquaculture, 295, 200-204.

González R., Celada J.D., García V., Carral J.M., González Á. and Sáez-Royuela M., 2011. Shelter and lighting in the intensive rearing of juvenile crayfish (Pacifastacus leniusculus, Astacidae) from the onset of exogenous feeding. Aquaculture Research, 42, 450-456.

New M.B., 1976. A review of dietary studies with shrimps and prawns. Aquaculture, 9, 101-144.

Sáez-Royuela M., Carral J.M., Celada J.D. and Muñoz C., 1995. Effects of management on survival and growth of stage 2 juvenile freshwater signal crayfish (Pacifastacus leniusculus Dana) under laboratory conditions. Aquaculture, 133, 123-133.

Sáez-Royuela M., Carral J.M., Celada J.D., Pérez J.R. and González A., 2007. Live feed as supplement from the onset of external feeding of juvenile signal crayfish (Pacifastacus leniusculus Dana. Astacidae) under controlled conditions. Aquaculture, 269, 321-327.

Van Stappen G., 1996. Use of cysts. In: Lavens P. and Sorgeloos P. (eds.), Manual on the Production and Use of Live Food for Aquaculture, FAO Fisheries Technical Paper 361, FAO, Rome, 107-136. 